\title{
Effect of Egyptian Roselle Biodiesel on Performance and Emissions of Diesel Engine
}

\author{
M.S. Gad ${ }^{1 *}$, H.M. Abu Hashish ${ }^{2}$ \\ ${ }^{1}$ Mechanical Engineering Department, Faculty of Engineering, Fayoum University, \\ Egypt. \\ ${ }^{2}$ Mechanical Engineering Department, Engineering Research Division, National \\ Research Centre, Giza, Egypt.
}

\begin{abstract}
$\mathbf{T}$ HE INCREASE in fuel demand consumption led to search about alternative fuels. Screw press was used to extract oil from roselle seeds at a temperature of $45{ }^{\circ} \mathrm{C}$ and motor speed of $30 \mathrm{rpm}$. Biodiesel was produced from roselle oil. Biodiesel blends were prepared from diesel and roselle biodiesel in volume percentages of 10 and $20 \%$. The experiments were run at engine load variations from start to full load. Thermal efficiency for roselle methyl ester blends was higher than diesel oil. Biodiesel blends achieved lower specific fuel consumptions of roselle methyl ester blends about diesel fuel. $\mathrm{CO}$ and $\mathrm{HC}$ emissions for biodiesel blends were decreased of diesel fuel. Biodiesel blends showed higher NOx emissions for biodiesel blends about diesel fuel. Roselle rmethyl ester blends up to $20 \%$ percentage are used as alternative fuels because performance and emissions were improved compared to diesel fuel.
\end{abstract}

Keywords: Roselle Seeds, Screw press, Biodiesel, Performance, Emissions.

\section{Introduction}

Biodiesel was produced from non-edible oils as alternative fuels [1]. Mechanical extraction press produces a higher oil yield. Screw press extraction method is considered a continuous process because of its higher oil yield [2].

Manual methods and simple implements were used to extraction Oil from seed but its traditional and less use. Oil extraction methods are mechanically and chemically [3-5]. Oil expellers such as Sundhara and Komet expeller are used for seeds pressing. The cooked seeds were pressed by screw press [6-10].

The hulled seeds like linseed, rapeseed, palm, jatropha have maximum oil yields between 45 to $55 \%$ of wt. dehulled seeds like sesame and jatropha have maximum oil yields between 70 to $75 \%$ of wt. Oil extraction rate was increased with extraction temperature increase and moisture content decrease. The Shirato model was used to describe pressing rate [11-14].
Roselle oil can be converted to biodiesel by using methanol with $\mathrm{KOH}$ catalyst. Methanol ratio to oil is 8 to 1 and catalyst concentration percentage to oil was $1.5 \%$ at reaction temperature $60{ }^{\circ} \mathrm{C}$ and time $60 \mathrm{~min}$. Soap formation at catalyst concentration more than $1.5 \%$ of oil lead to decreased biodiesel content. Physical and chemical characterizations of biodiesel were within ASTM standards. Roselle oil could be substitute feedstock for biodiesel production. The yield of roselle oil increases with the increase in pressing pressure up to $30 \mathrm{MPa}$ at pressing temperature of $100^{\circ} \mathrm{C}[15]$. Brake thermal efficiency for biodiesel blend B5 increased about $6.64 \%$ as compared to diesel fuel. There were increases in specific fuel consumptions for biodiesel blends about diesel fuel. Specific fuel consumption for biodiesel blend B5 decreased about $17.5 \%$ as compared to diesel fuel. Smoke level was decreased for biodiesel blend B5 compared to diesel fuel [16].

The research aims running of roselle biodiesel blends with diesel fuel in diesel engine. Roselle oil is extracted from roselle seeds by screw

*Corresponding author e-mail: mgad27@yahoo.com

DOI: 10.21608 /ejchem.2018.4425.1392

C2017 National Information and Documentation Center (NIDOC) 
press. Biodiesel was produced from roselle oil by. Physical and chemical properties of roselle metyl ester blends were near to diesel oil. Effects of roselle biodiesel blends on performance and exhaust emissions of a diesel engine were investigated.

\section{Materials and Methods}

Oil extraction method

Roselle fruits were obtained from Upper Egypt. The seeds were grouped into good maturity. Roselle seeds were peeled. Mechanical pressing is a continuous extraction method which produces higher oil yield of $20 \%$. Roselle oil was extracted using a screw press at extraction temperature of $45^{\circ} \mathrm{C}$ and motor speed of $30 \mathrm{rpm}$.

\section{Biodiesel production process}

Biodiesel was produced by transesterification in a conical flask has condenser using a hot plate with magnetic stirrer. The flask was charged with roselle oil and preheated to $65^{\circ} \mathrm{C}$. Sodium hydroxide $(\mathrm{NaOH})$ by weight $1 \%$ as a catalyst was dissolved in methanol of 6:1 molar ratio. The produced solution was put and the reaction was timed (1.5 hours). The mixture was put to separate glycerol from biodiesel. Roselle biodiesel methyl was dried at $100{ }^{\circ} \mathrm{C}$. Mixing of diesel oil with biodiesel was done at different volume proportions of 10 and $20 \%$. Table 1 shows the density, kinematic viscosity, flash point and heating values of biodiesel blends.

Variations in densities and viscosities at different temperature for roselle biodiesel blends are shown in Fig.1. The temperature has a significant effect on density and viscosity of biodiesel blends. Biodiesel density and viscosity was decreased with temperature increase.

\section{Experimental}

The experimental runs were carried out on a single cylinder diesel engine with a maximum power of $5.775 \mathrm{~kW}$ at $1500 \mathrm{rpm}$. Specifications of diesel engine are shown in Table 2. Schematic diagram of the test engine was shown in Fig.2. $\mathrm{AC}$ generator of maximum power $10.5 \mathrm{~kW}$ is coupled to the diesel engine. A sharp edged orifice mounted in the side of air box to evaluate the air flow rate. A manometer was used to measure orifice pressure drop. Temperatures were measured at different points as air manifold and exhaust gas. Diesel and biodiesel oils were fed to the engine and its flow rates were measured. MRU DELTA 1600-V gas analyzer and OPA 100 smoke meter were used for exhaust emissions and smoke opacity measurements, respectively. The engine loads were varied at rated speed of $1500 \mathrm{rpm}$.

\section{Results and Discussions}

Effect of roselle biodiesel blends on specific fuel consumption

Specific fuel consumptions for biodiesel blends with engine load were measured as described in Fig.3. Specific fuel consumptions for roselle methyl ester blends are lower than diesel fuel because densities and heating values are near to diesel fuel. Diesel engine consumes higher biodiesel fuel than diesel oil at the same power. The decreases in specific fuel consumptions of biodiesel blends B20 and B10 are about diesel fuel by about 4 and $9 \%$, respectively compared to diesel oil [10, 15].

TABLE 1. Physical and chemical properties of biodiesel blends B10 and B20 compared to diesel oilusing ASTM standards.

\begin{tabular}{lcccc}
\hline \multicolumn{1}{c}{ Properties } & Method & Diesel oil & $\begin{array}{c}\text { Roselle Biodiesel } \\
\text { (B10) }\end{array}$ & $\begin{array}{c}\text { Roselle Biodiesel } \\
\text { (B20) }\end{array}$ \\
\hline $\begin{array}{l}\text { Density at } 15.56^{\circ} \mathrm{C} \\
\text { Kinematic viscosity, cSt, at } 40^{\circ}\end{array}$ & ASTM D-4052 & 835 & 840 & 844 \\
$\mathrm{C}$ & ASTM D-445 & 2.5 & 3.3 & 5.99 \\
Flash point, ${ }^{\circ} \mathrm{C}$ & ASTM D-93 & 72 & 85 & 90 \\
Lower heating value $\mathrm{kJ} / \mathrm{Kg}$ & ASTM D-224 & 41670 & 41017 & 40866 \\
\hline
\end{tabular}

Egypt.J.Chem. 61, No. 6 (2018) 

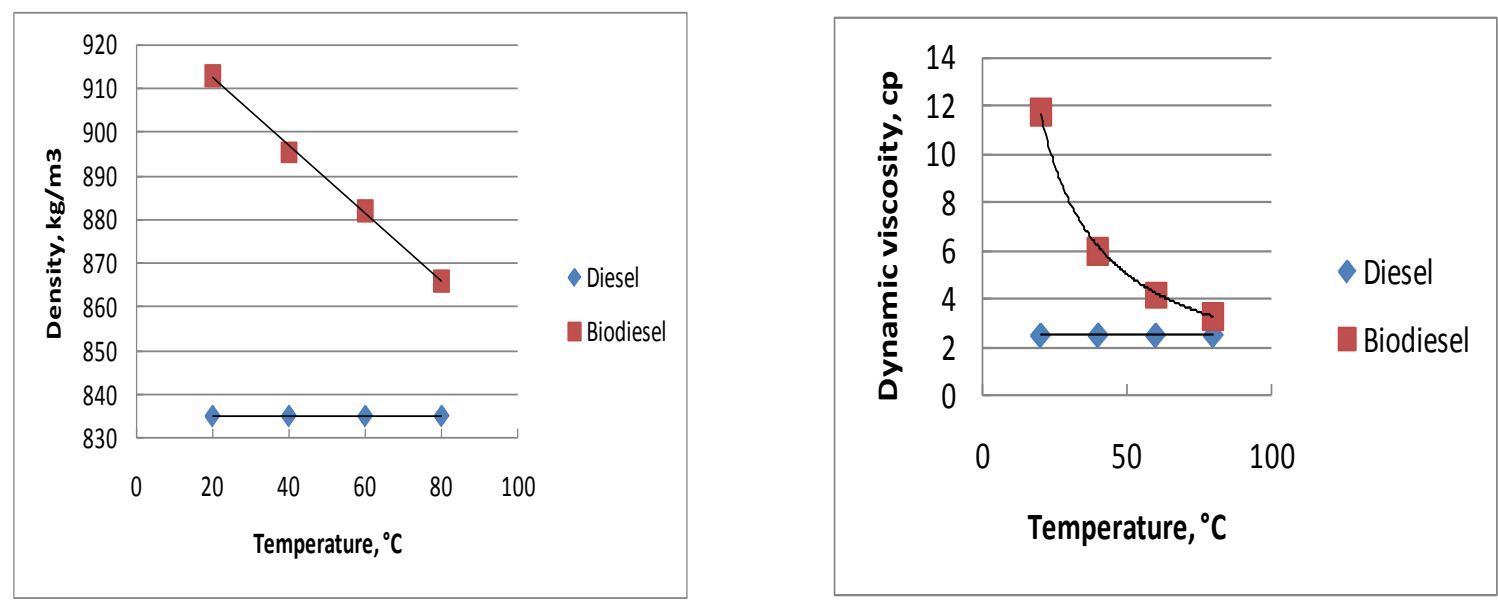

Fig. 1. Effect of temperature on density and viscosity of biodiesel.

Effect of roselle biodiesel blends on thermal efficiency

Figure 3 showed thermal efficiencies for roselle methyl ester blends as compared to diesel fuel. Biodiesel blends produced higher thermal efficiencies compared to diesel fuel due to volatility improvement. Thermal efficiencies of biodiesel blends B20 and B10 achieved maximum increases about diesel fuel by about 4.5 and $10 \%$, respectively $[15,17,18]$.

Effect of roselle biodiesel blends on exhaust gas temperature

Roselle biodiesel blends have effects on exhaust gas temperatures at engine loading variation as shown in Fig.4. The increase in thermal efficiency of biodiesel blends about diesel oil because of heat loss decrease. The increase in engine load led to an increase in heat loss. The decreases in exhaust gas temperatures are shown for roselle methyl ester blends in comparison to diesel oil. Exhaust gas temperatures values for biodiesel blends B10 and B20 were 310, 275 and $290^{\circ} \mathrm{C}$ at full load, respectively $[15,17,18]$.

Effect of roselle biodiesel blends on air-fuel ratio

Air- fuel ratios for roselle methyl ester blends at different loads were shown in Fig. 4. Air- fuel ratios for biodiesel blends were higher than diesel fuel because of fuel consumption decrease with biodiesel percentage increase. Air- fuel ratios for diesel and roselle methyl ester blends B10 and B20 were 22, 21 and 19 at full load, respectively $[17,18]$.

TABLE 2. Engine specification.

\begin{tabular}{ll}
\hline Engine parameters & Specifications \\
\hline Type & DEUTZ F1L511 \\
Number of cylinders & 1 \\
Number of Cycles & Four stroke \\
Cooling type & Air cooled \\
Bore (mm) & 100 \\
Stroke (mm) & 105 \\
Compression ratio & $17.5: 1$ \\
Fuel injection advance angle & $24^{\circ}$ BTDC \\
Rated brake power (kW) & 5.775 at $1500 \mathrm{rpm}$ \\
Number of nozzle holes & 1 \\
Injector opening pressure (bar) & 175 \\
\hline
\end{tabular}




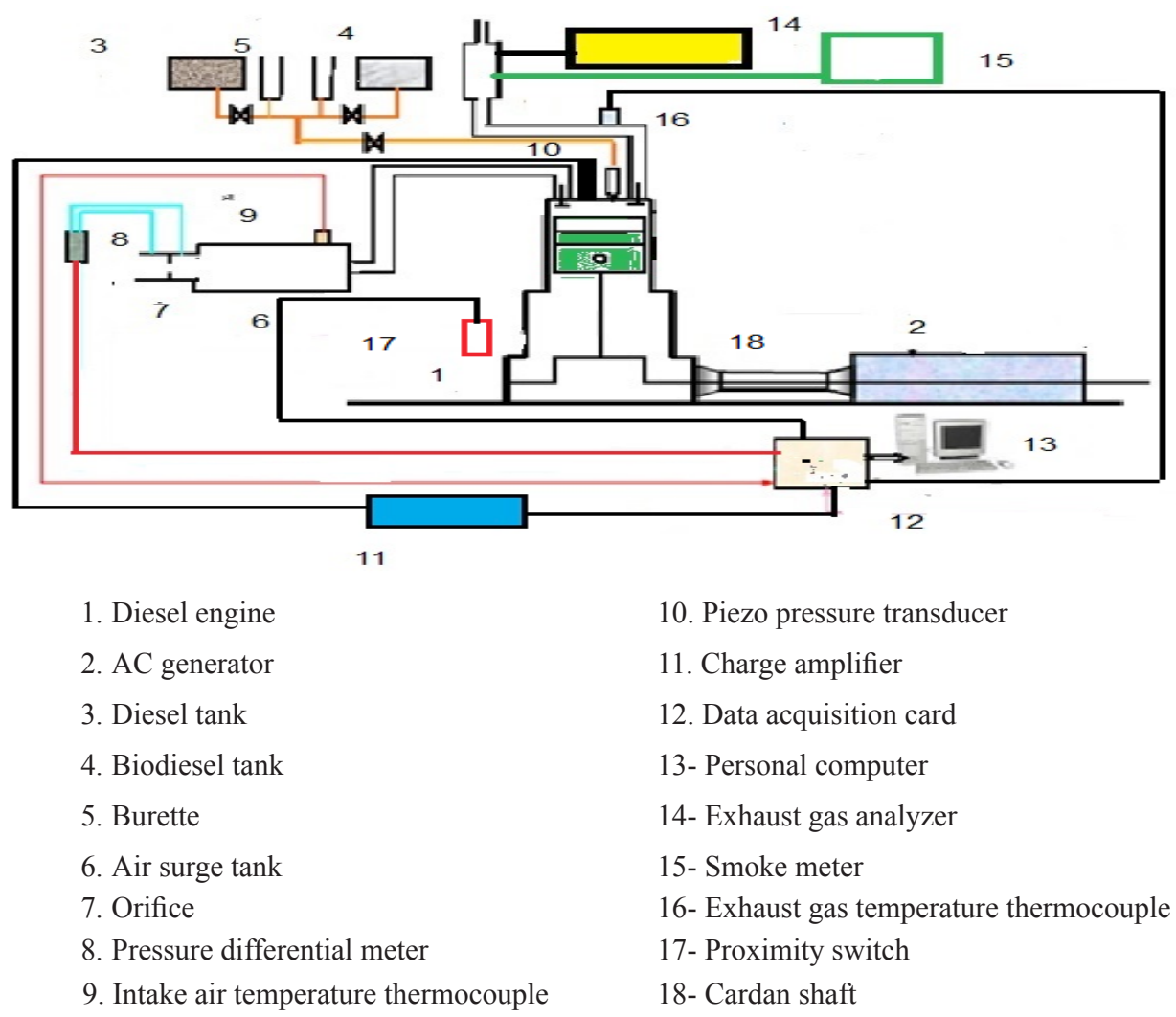

Fig. 2. Schematic diagram of the experimental setup.

Effect of roselle biodiesel blends on mechanical efficiency

The increase in mechanical efficiency with engine output power for biodiesel blends is shown in Fig.5 which due to friction losses increase. Mechanical efficiency for biodiesel blends increased about diesel fuel due to frictional power loss increase. Mechanical efficiency values for roselle methyl esters blends B10 and B20 were 57,62 and $64 \%$ at full load, respectively.

\section{Effect of biodiesel blends on $\mathrm{CO}_{2}$ emissions}

Values of carbon dioxide emission for biodiesel blends were shown in Fig.6. $\mathrm{CO}_{2}$ emissions are higher for pure biodiesel blends about diesel fuel. The trend of $\mathrm{CO}_{2}$ emission increased because of higher fuel consumption. Biodiesel blends achieved higher $\mathrm{CO}_{2}$ emissions about diesel oil because of higher oxygen content in roselle methyl ester. Values of $\mathrm{CO}_{2}$ emissions for diesel and biodiesel blends B10 and B20 were 1.7, 1.8 and $2 \%$, respectively at full load $[15,17,18]$.

Effect of roselle biodiesel blends on CO emissions

Carbon monoxide values at different engine loads are shown in Fig.7. CO emissions decreased at lower loads and then increased with load increase. Carbon monoxide emissions decrease for roselle methyl ester blends were because of inbuilt oxygen and lower carbon content compared to diesel oil. Oxygen content in biodiesel blends is helpful for improved combustion $\mathrm{CO}$ emissions reductions. Higher reductions in carbon monoxide emissions for biodiesel blends B10 and B20 about diesel fuel were 6 and $12 \%$, respectively at full load $[15,17,18]$.

Effect of roselle biodiesel blends on $\mathrm{NO}_{x}$ emissions Influence of engine output power on $\mathrm{NO}_{x}$ emissions for biodiesel blends are described in Fig.8. The increase in $\mathrm{NO}_{\mathrm{x}}$ emissions with engine load was due to the increase of cylinder temperature which led to thermal $\mathrm{NO}_{\mathrm{x}}$ formation. Higher cylinder temperature and adiabatic flame temperature led to higher $\mathrm{NO}_{\mathrm{x}}$ emission. Oxygen content in biodiesel blends led to $\mathrm{NO}_{\mathrm{x}}$ emission increase compared to diesel fuel. $\mathrm{NO}_{\mathrm{x}}$ emissions values for diesel and biodiesel blends B10 and B20 were 85, 87 and 92 ppm at full load, respectively $[15,17$, 18]. 

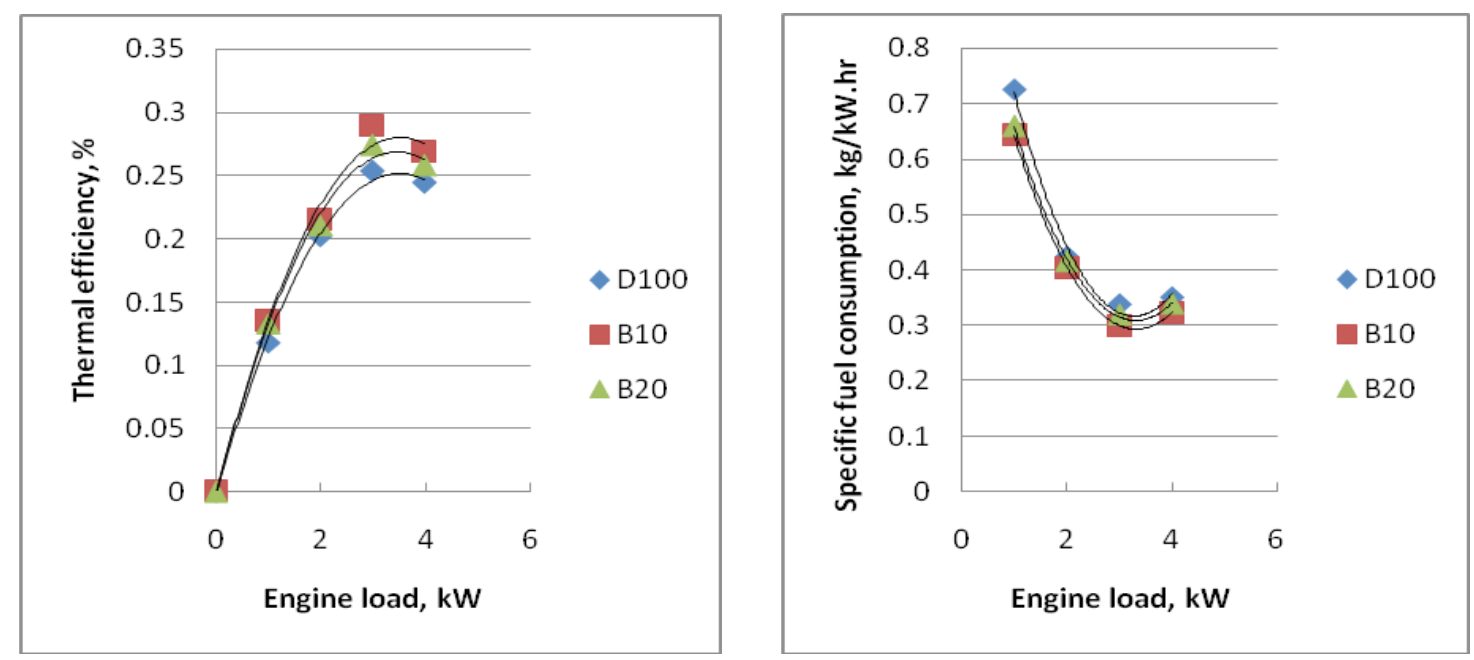

Fig. 3. Variation of thermal efficiency and specific fuel consumption with engine load for roselle biodiesel blends.
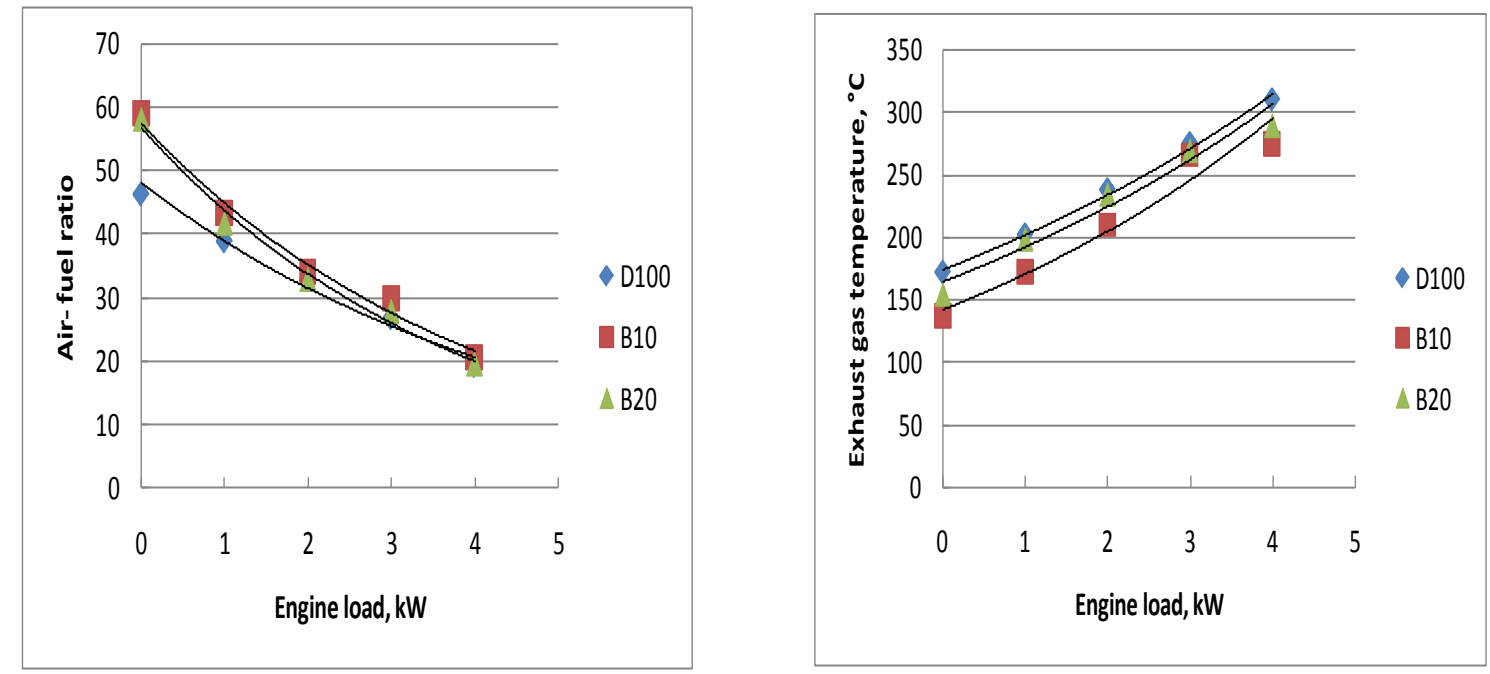

Fig. 4. Variation of air-fuel ratio and exhaust gas temperature with engine load for roselle biodiesel blends.

Effect of roselle biodiesel blends on HC emissions

Figure 9 showed hydrocarbons emissions for biodiesel blends at different loads. There are decreases in $\mathrm{HC}$ emission at engine lower loads and increases with engine load increase because of fuel rich mixture and deficiency of oxygen. Biodiesel blends achieved lower HC emissions at all engine loads in comparison to diesel fuel. Maximum reductions in $\mathrm{HC}$ emissions for biodiesel blends B10 and B20 about diesel fuel at full load were 10 and $13 \%$, respectively $[15$, $17,18]$.

Effect of roselle biodiesel blends on smoke opacity Effect of roselle biodiesel blends on smoke

\section{opacity variations}

Variations of smoke opacity for roselle methyl esters blends at engine loading variations are described in Fig.10. Smoke emissions increase was due to fuel consumption increase. Diesel fuel has branched and ring structures which led to increasing the smoke levels. Smoke emissions of roselle methyl esters blends were lower than diesel oil due to oxygen presence which led to improved combustion. Biodiesel blends B10 and B20 showed decreases in smoke emissions about diesel fuel at full load by about 15 and $22 \%$, respectively. 


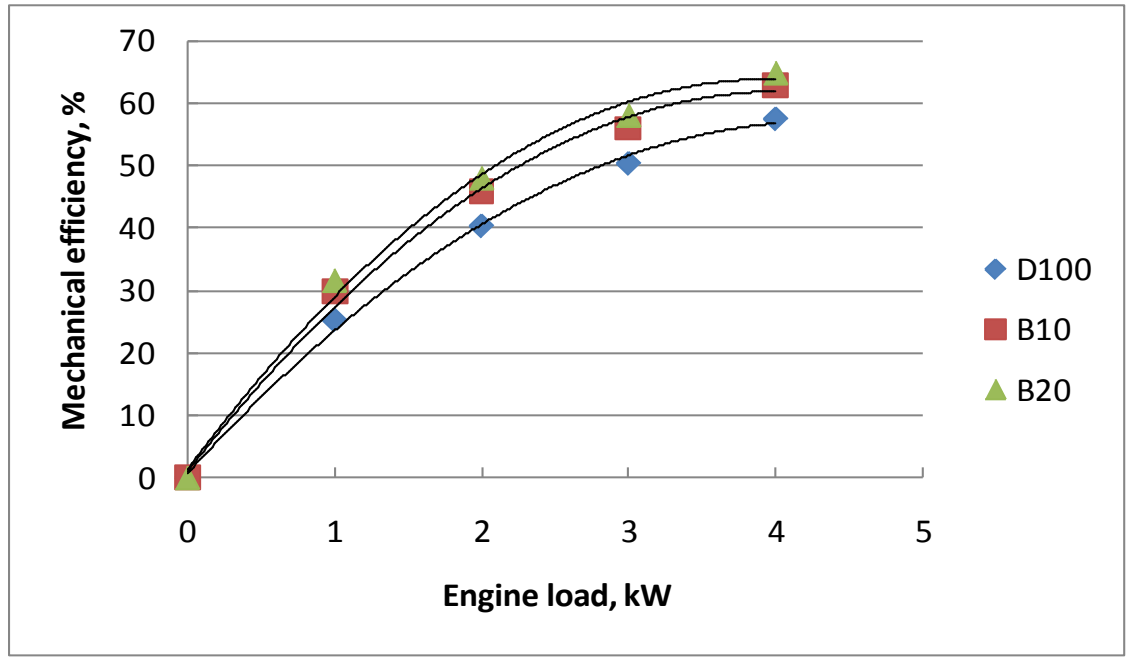

Fig. 5. Variation of mechanical efficiency with engine load for roselle biodiesel blends.

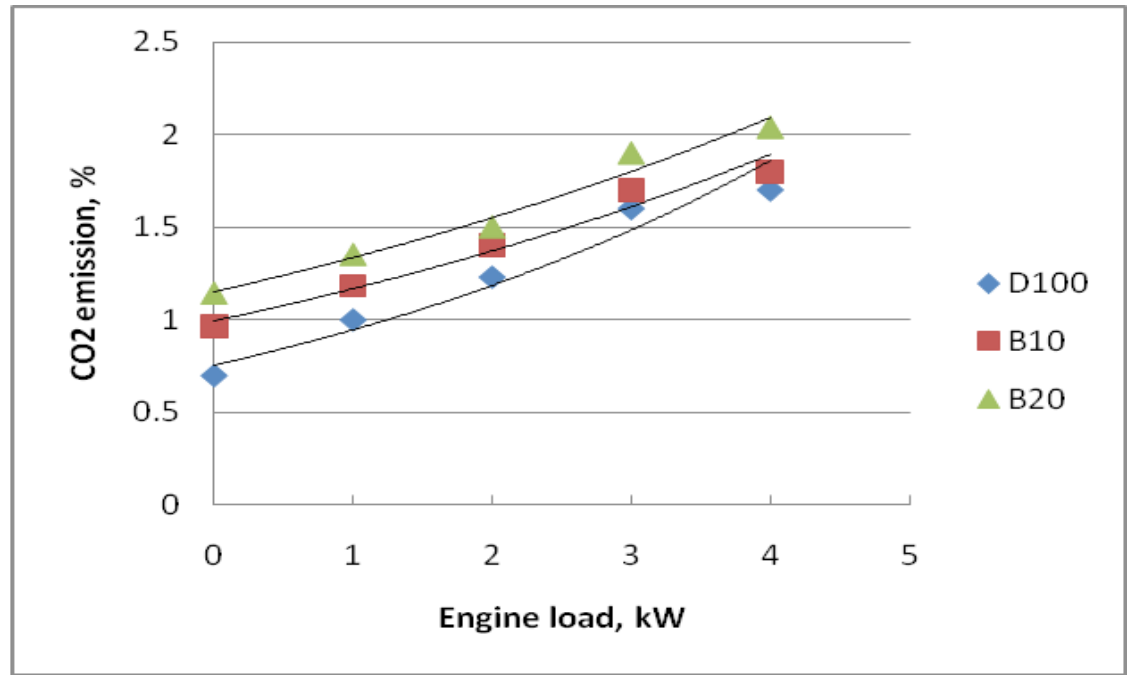

Fig. 6. Variation of air-fuel ratio with engine load for roselle biodiesel blends.

\section{Conclusion}

A diesel engine was operated with biodiesel blends B10 and B20. Exhaust emissions and performance were investigated at engine loads variations. Effect of biodiesel blends on performance parameters and exhaust emissions were evaluated in comparison with diesel fuel. The following conclusions can be summarized as:

1. Biodiesel blends showed improvements in thermal efficiencies about diesel fuel and decreases in specific fuel consumptions.

2. Roselle methyl esters blends achieved lower values about diesel oil at all engine loads.
3. There were decreases in carbon monoxide, hydrocarbons and smoke emissions of biodiesel blends compared to diesel fuel.

4. Carbon dioxide and NOx emissions increased for roselle methyl esters blends about diesel fuel.

5. Exhaust emissions and performance of a diesel engine burning roselle biodiesel blends up to $20 \%$ volume percentage with diesel fuel are produced higher improvements in performance and lower exhaust emissions concentrations. 


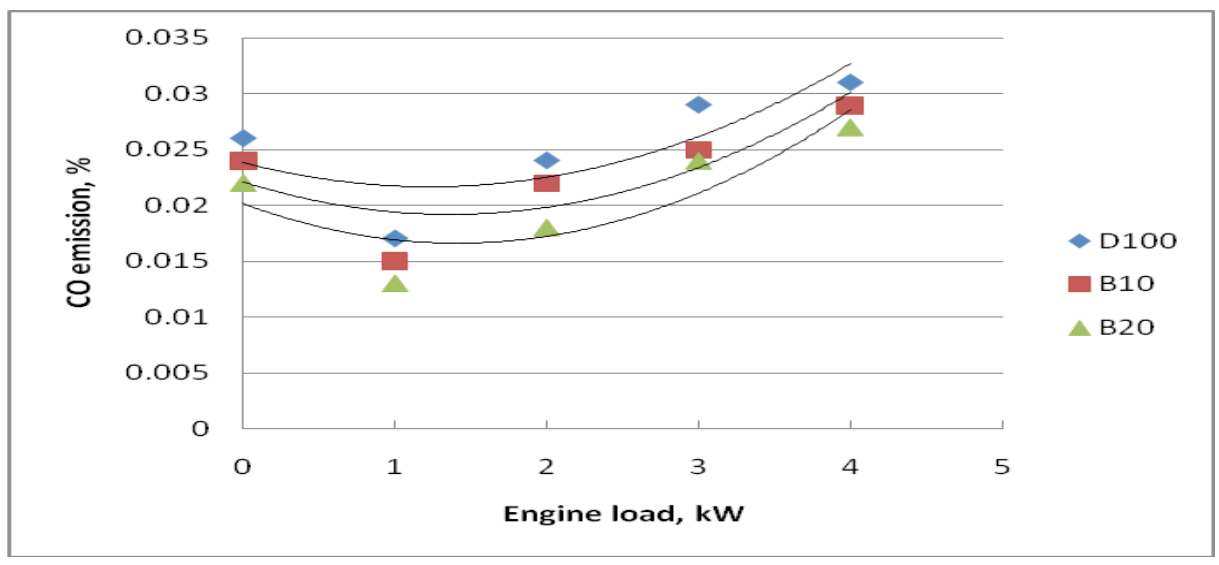

Fig.7. Variation of $\mathrm{CO}$ emission with engine load for roselle biodiesel blends.

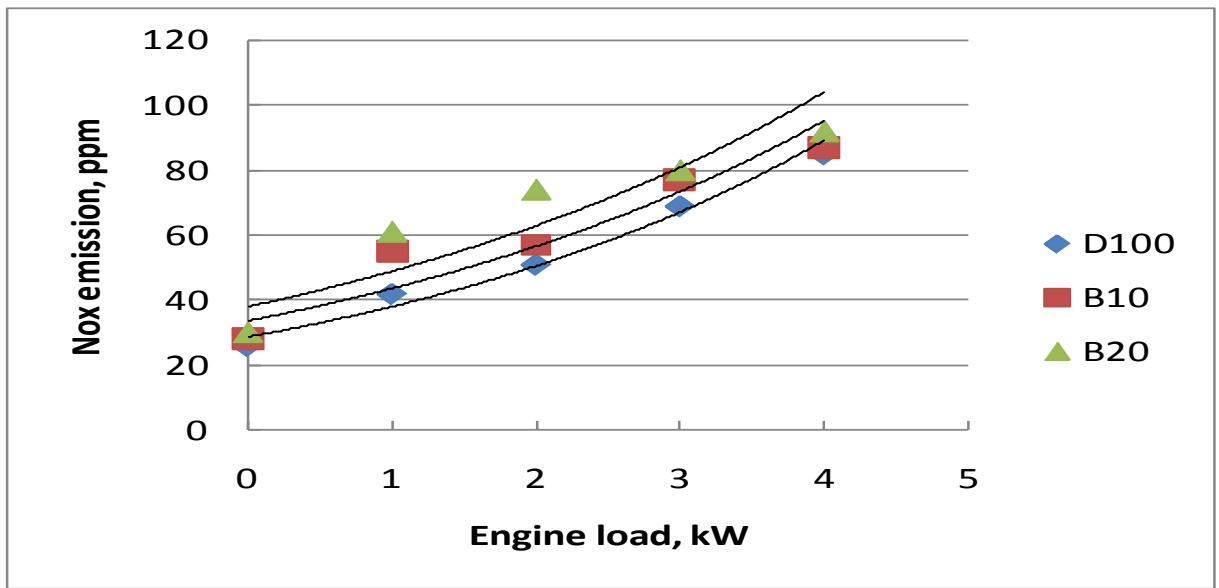

Fig. 8. Variation of $\mathrm{NO}_{\mathrm{x}}$ emission with engine load for roselle biodiesel blends.

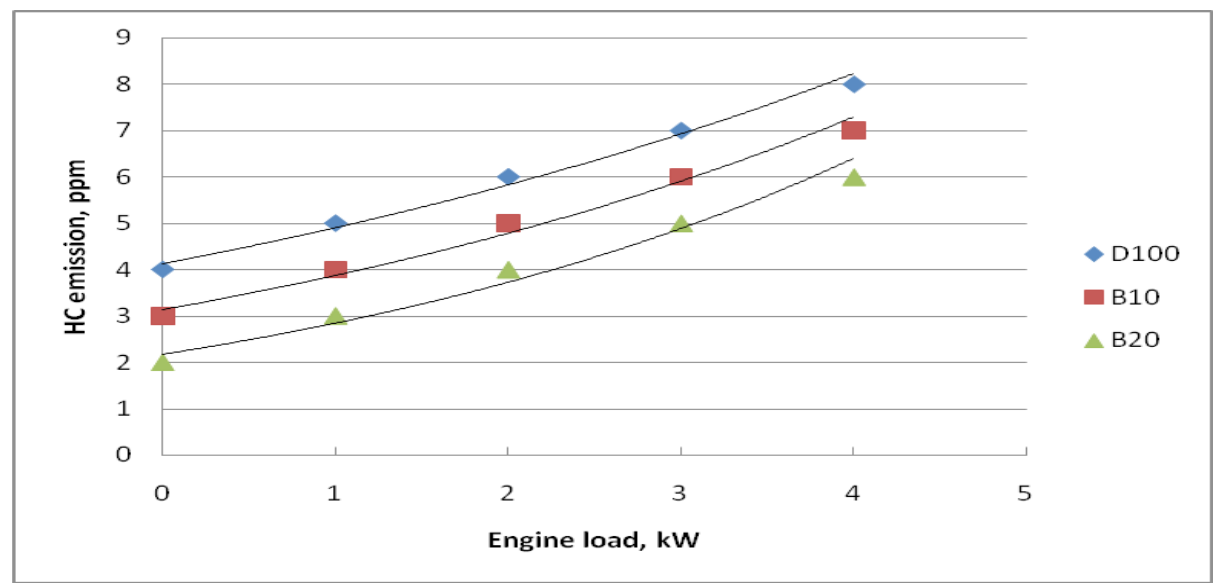

Fig. 9. Variation of $\mathrm{HC}$ emission with engine load for roselle biodiesel blends. 


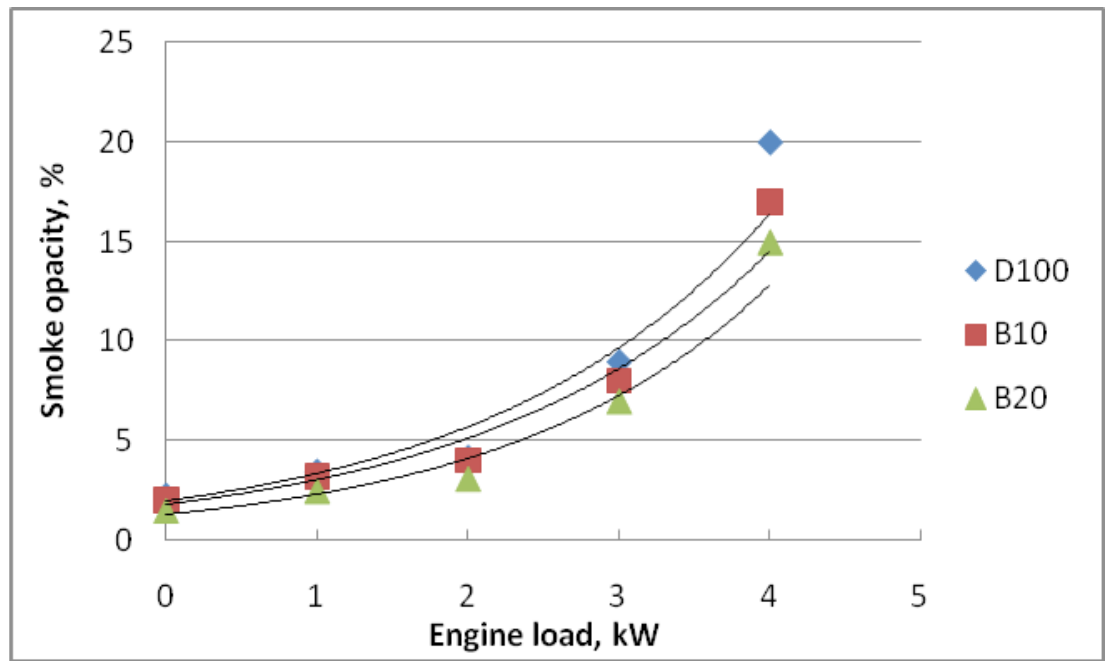

Fig. 10. Variation of HC emission with engine load for roselle biodiesel blends.

\section{References}

1. Raja, S.A., Smart, D.S.R. Lee, C.L.R., Biodiesel production from jatropha oil and its characterization, Research Journal of Chemical Sciences, 1(1), 1-7 (2011).

2. Ibrahim, Said M. A., Abed, K.A., Gad, M.S., Abu Hashish, H.M., Optimum Oil Yield from Egyptian Jatropha Seeds Using Screw Press, International Journal of Mechanical \& Mechatronics Engineering IJMME-IJENS, 17(1), 47-56 (2017).

3. Koh, M.Y., Ghazi, T.I. Mohd, A review of biodiesel production from Jatropha curcas L. oil, Renewable and Sustainable Energy Reviews, 15(5), 2240-2251 (2011).

4. Shah, S., Sharma, A., Gupta, MN, Extraction of oil from Jatropha curcas L. seed kernels by enzyme assisted three phase partitioning, Ind. Crop Prod. Journal, 20(3), 275e9 (2004).

5. Shah, S., Sharma, A., Gupta, MN., Extraction of oil from Jatropha curcas L. by combination of ultrasonication and aquaeous enzymatic oil extraction, Bioresour. Technol., 96, 121e3 (2004).

6. Kumar, A., Sharma, S., An evaluation of multipurpose oil seed crop for industrial uses (Jatropha curcas L.): a review, Ind. Crops Prod., 28(1), 1e10 (2008).

7. Sirisomboon, P., Kitchaiya, P., Pholpho, T., Mahuttanyavanitch, W., Physical and mechanical Properties of Jatropha curcas L. fruits, nuts, and kernels, Biosyst. Eng, 97, 201e7 (2007).
8. Evangelista, R.L., Isbell, T.A., Cermak, S. C., Extraction of pennycress (Thlaspi arvense L.) seed oil by full pressing, Industrial Crops and Products, 37(1), 76-81 (2012).

9. Evangelista, R.L., Cermak, S.C., Full-press oil extraction of cuphea (PSR23)seeds, J. Am. Chem. Soc., 84, 1169-1175 (2007).

10. Tambunan, A.H., Situmorang, J.P., Silip, J.J., Joelianingsih, A., Araki, T., Yield and physicochemical properties of mechanically extracted crude Jatropha curcas L oil, Biomass and Bioenergy, 43, 12-17 (2012).

11. Oyinlola, A., Ojo, A., L.O. Adekoya, L. O., Development of a laboratory model screw press for peanut oil expression, Journal of Food Engineering, 64(2), 221-227 (2004).

12. Pradhan, R.C., et al., Oil expression from Jatropha seeds using a screw pressexpeller, Biosystems Engineering, 109(2), 158-16 (2011).

13. Willems, P., Kuipers, N. J. M., De Haan, A. B., Hydraulic pressing of oilseeds: Experimental determination and modeling of yield and pressing rates. Journal of Food Engineering, 89(1), 8- 16 (2008).

14. Ofori-Boateng, C., Teong, L. K., JitKang, L., Comparative exergy analyses of Jatropha curcas oil extraction methods: Solvent and mechanical extraction processes, Energy Conversion and Management, 55, 164-171 (2012).

15. Nakpong, P., Wootthikanokkhan, S., Roselle (Hibiscus sabdariffa L.) oil as an alternative 
feedstock for biodiesel production in Thailand, Fuel, 89, 1806-1811 (2010).

16. Bamg boye, S. I., Adejumo, O. I., Effects of processing parameters of Roselle seed on its oil yield, International Journal of Agricultural and Biological Engineering (IJABE), 4(1), 82-86 (2011)

17. Gad, M.S., El-Baz, F.K., El. Kinawy, O.S., Performance of Diesel Engines Burning Used Cooking Oil (UCO) Biodiesel, International
Journal of Mechanical\& Mechatronics Engineering IJMME-IJENS, 15(3), 74-80, (2015).

18. El-Baz, F.K., Gad, M.S., Abdo, S. M., Abed, K. A., Matter, I. A., Performance and Exhaust Emissions of a Diesel Engine Burning Algal Biodiesel Blends, International Journal of Mechanical\& Mechatronics Engineering IJMME-IJENS, 16(3), 150-157, (2016).

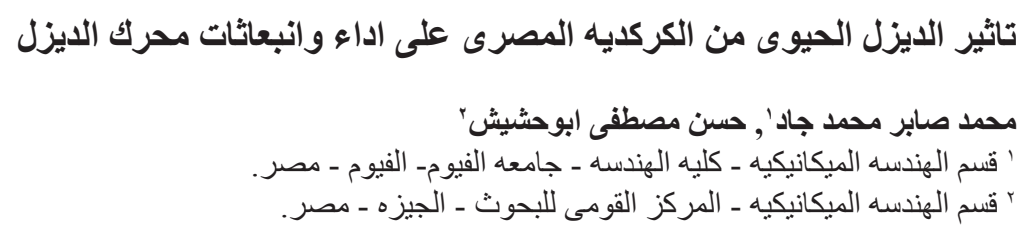

الزياده المستمره في الطلب العالمي على الطاقة واستهلاك الوقود الحفرى المستنفذ وانبعانات العادم والاحتباس

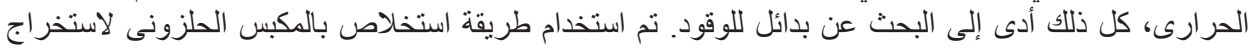

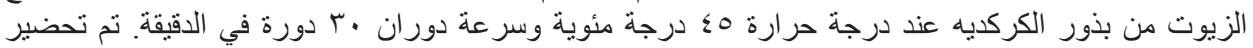

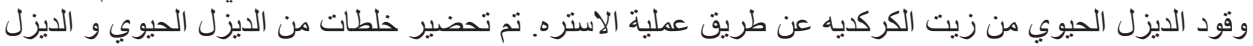

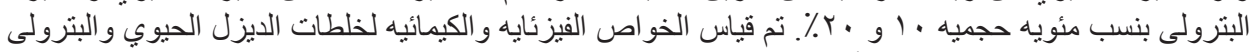

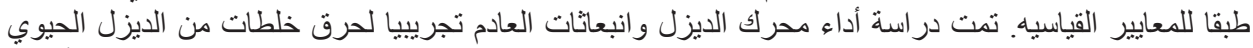

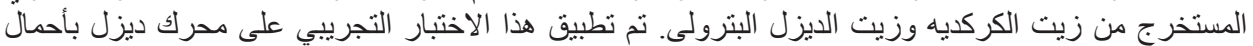

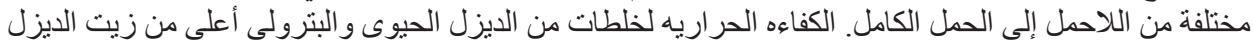

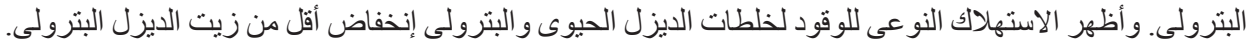

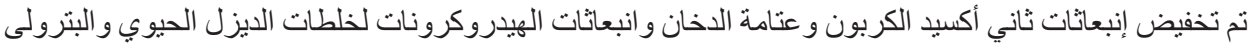

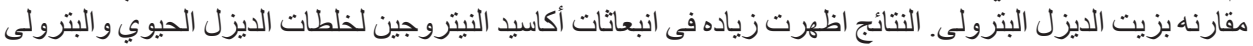

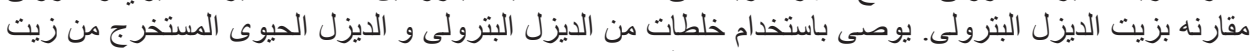

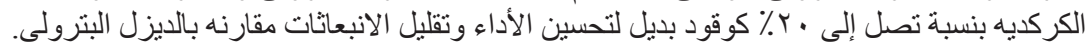

